\title{
Differentiation of Diatom Guilds in Extreme Environments in the Andean Altiplano
}

\author{
Inger Heine-Fuster ${ }^{1 *}$, Camila López-Allendes ${ }^{1}$, Adriana Aránguiz-Acuña ${ }^{2 *}$ and \\ David Véliz ${ }^{1,3,4}$
}

${ }^{1}$ Departamento de Ciencias Ecológicas, Facultad de Ciencias, Universidad de Chile, Santiago, Chile, ${ }^{2}$ Departamento de Biología, Facultad de Ciencias, Universidad de Tarapacá, Arica, Chile, ${ }^{3}$ Instituto de Ecología y Biodiversidad (IEB), Universidad de Chile, Santiago, Chile, ${ }^{4}$ Núcleo Milenio de Ecología y Manejo Sustentable de Islas Oceánicas (ESMOI), Universidad Católica del Norte, Departamento de Biología Marina, Coquimbo, Chile

\section{OPEN ACCESS}

Edited by:

Eugenia López-López, Instituto Politécnico Nacional de

México (IPN), Mexico

Reviewed by:

Luiz Ubiratan Hepp, Federal University of Mato Grosso do

Sul, Brazil

Richard Greenfield, University of Johannesburg, South

Africa

*Correspondence:

Inger Heine-Fuster

i.heinefuster@gmail.com

Adriana Aránguiz-Acuña aaranguiza@academicos.uta.cl

Specialty section:

This article was submitted to

Freshwater Science,

a section of the journal

Frontiers in Environmental Science

Received: 28 April 2021

Accepted: 30 June 2021

Published: 02 August 2021

Citation:

Heine-Fuster I, López-Allendes $C$, Aránguiz-Acuña $A$ and Véliz D (2021)

Differentiation of Diatom Guilds in

Extreme Environments in the Andean Altiplano.

Front. Environ. Sci. 9:701970. doi: 10.3389/fenvs.2021.701970
The Andean Altiplano is characterized by its isolation, high altitude ( $>3,600 \mathrm{~m}$ a.s.I.), and a unique biodiversity, containing water systems such as lakes, rivers, wetlands, and salt flats. Near the southernmost area of the Andean Altiplano are two salt flats, Carcote and Ascotán, the former almost undisturbed by human intervention and the latter historically intervened with by brine mining. These mining activities deplete, pollute, and alter water flow, suggesting a significant threat to ecosystem functions. With regard to identifying the main factors promoting biotic community differentiation in these salt flats at different levels of human intervention, the aim of this study was to compare diatom community indices by guild (high-profile, low-profile, and motile) between these systems with a functional perspective, their relationship to environmental conditions, and the potential anthropic impact on their community structures. Diatom guilds were compared between salt flats based on their diversity, species richness, and abundance relative to ionic concentrations and granulometry. Beta diversity and the percentages of nestedness and turnover for each guild were also estimated. Results showed significant differences in ecological variables between the two salt flats. The largest values of species abundance, richness, and diatom diversity were measured in Carcote, suggesting greater primary productivity and diversity. The results also showed that the species composition of the motile guild was more differentiated between salt flats than those of other guilds (with the greatest diversity and richness), suggesting that motile diatoms are a key guild in maintaining the diatom community and that species from this guild are more sensitive to local conditions from each salt flat. Additionally, beta diversity in all guilds was mainly explained by turnover rather than nestedness, and the turnover was the highest for the motile and low-profile guilds. A more heterogeneous community was observed in Ascotán, showing that the mechanisms of diversity maintenance, such as dispersion abilities, were salt flat dependent. This suggests that the highest diversity could be related to human use, which challenges us to reexamine the effectiveness of past conservation activities in the area and to develop future strategies including both connected basins.

Keywords: guilds, salt flats, species turnover, nestedness, Ascotán, Carcote, beta diversity 


\section{INTRODUCTION}

The Andean Altiplano is in the Dry Puna ecoregion, close to the Atacama Desert, one of the driest and oldest worldwide. The Dry Puna stretches from approximately 17 to $27^{\circ} \mathrm{S}$ in southwest Bolivia, northeast Argentina, and northern Chile in the eastern Atacama Desert. This area is characterized by low annual precipitation ( $<200 \mathrm{~mm}$ average annual precipitation), mainly restricted to summer months, and high evaporation, promoting a negative hydric balance (Márquez-García et al., 2009). Most basins in this region are endorheic, with the occurrence of salt lakes and shallow peatlands or salares (Squeo et al., 2006; Marazuela et al., 2019). The Andean Altiplano is subject to extreme environmental conditions. High altitude and the resulting thin atmosphere cause high solar irradiance and UV radiation and low ozone layer protection, with substantial daily and yearly temperature fluctuations. The orography is dominated by volcanoes with ice-covered peaks (Jacobsen and Dangles, 2017).

All these characteristics pose challenges for organisms with more common metabolisms, but, as has been noted by Albarracín et al. (2011; 2016), the description of "extreme environment" is given from an anthropic perspective since highly adapted forms of life exist in these ecosystems. Thus, this extreme environment of high aridity, salinity in the case of salt flats, high levels of UV radiation, and naturally high arsenic concentrations (Tapia et al., 2019) represents a severe environmental filter, where polyextremophiles have evolved several behavioral and metabolic strategies to survive (Albarracín et al., 2016).

Previous studies in the Altiplano have revealed its unique diversity, from bacteria (Dorador et al., 2013; Aguilar et al., 2016; Dorador et al., 2020) to invertebrates and vertebrates (e.g., Collado et al., 2011; Collado and Méndez, 2012, 2013; Cuevas et al., 2020). The algal community is composed of chlorophytes, cyanophytes, and diatoms in Altiplano water bodies such as Chungará Lake (Dorador et al., 2003), Titicaca Lake (Fritz et al., 2012), and the Ascotán and Carcote salt flats (MárquezGarcía et al., 2009). Díaz and Maidana (2005) pointed out that diatom ecology has not been widely studied in the salt flats in South America, and such studies in Chile were carried out at the beginning of the 20th century. Although the crucial role of diatoms as main primary producers and contributors of a great diversity of phytobenthos and plankton (Rumrich et al., 2000) to Bolivian Altiplano systems has been recognized (Iltis et al., 1984), studies focused on studying the ecological groups in the Chilean Altiplano are still scarce and are mainly carried out on invertebrate fauna as indicators of specific processes (e.g., Collado et al., 2011; Collado and Méndez, 2012, 2013; Cuevas et al., 2020). Taxonomic diversity is the most common measure of biodiversity; however, the unique use of the taxonomic criterion assumes that the taxa are equally distinct from one another, disregarding the fact that communities are composed of species with different evolutionary histories and a diverse array of ecological functions (Cardoso et al., 2014). Thus, there is a growing interest in including complementary representations of biodiversity, such as phylogenetic and functional diversity (Devictor et al., 2010; Cardoso et al., 2014).
Studies of diatom diversity have recognized that the turnover rate is high on the regional scale of the South American subtropical zone, in which the climate and local landscape characteristics are the main drivers of community composition (Benito et al., 2018a). Specifically, in the Altiplano systems, environmental conditions have been shown to be key influences on the biogeographic distribution patterns for diatom species (Benito et al., 2018b) and other microorganisms (Hanson et al., 2012), showing a strong effect on community composition, although constrained by speciesspecific dispersal limitations.

Landscape patchiness in the fragmented salt flats of the Andean Altiplano makes it necessary to address the study of diatom distribution from a functional perspective, considering traits associated with ecological guilds, such as those proposed by Passy (2007) and Rimet and Bouchez (2012). These studies have described guilds which classified the species by their use of space at the microhabitat level, providing information about resistance to disturbances such as water turbulence, low nutrient availability, and pollution. Passy (2007) described three guilds among diatoms: 1) low-profile species, characterized by small size and resistance to high current and low nutrient availability, 2) high-profile species, comprising large-sized diatoms abundant under nutrient enrichment, and 3) motile species, characterized by sensitivity to disturbances. Thus, categorizing diatom species using this functional classification, more than taxonomic grouping, gives valuable information on the environmental conditions of the different communities (Rimet and Bouchez, 2011) and the dispersal abilities of the species.

The Ascotán and Carcote salt flats are two adjacent basins located in the Andean Altiplano. The former system has been exploited for mineral extraction for over 100 years (Chong et al., 2010), whereas the latter is not subject to significant anthropic perturbation. The aforementioned environmental conditions, along with high geographic isolation, have exerted strong selective pressures on the local vegetation and fauna, promoting high endemism of both vertebrates and invertebrates in these basins (e.g., Vila et al., 2007; Collado and Méndez, 2013; Vila et al., 2013). Notably, besides high endemism rates, these waterscapes also have high species richness compared to the extensive desert areas adjacent to the salt flats (Ahumada et al., 2011). However, there are no previous studies focused on the study of endemism, genetic diversity, or functional diversity of diatoms in these systems, despite the relevance of knowing the inter- and intra-basin diversity, especially under conditions of increasing anthropic pressures. Along with their contribution to primary productivity on the Ascotán and Carcote salt flats (Márquez-García et al., 2009), diatoms are a practical group to study, since the diversity in growth forms represents differences in resistance to disturbance and resource use (Passy 2007).

Despite the ecological and social relevance of the Ascotán and Carcote salt flats, neither of these salt flats has been categorized for protection by the Chilean state or the International Ramsar Convention. Thus, the water and minerals present in these systems are considered mere economic resources in Chilean legislation. Given the present and potential future disturbances 
projected in Ascotán, the landscape's integrity could be at stake along with the ecological community structure. Many ecological effects could be expected at different levels, such as alteration of landscape connectivity and consequent dispersal opportunities (Heino et al., 2013), reduction of ecological richness facing increasing hydric scarcity (López and Vargas, 2021), reduction of community functional redundancy (Gutiérrez-Cánovas et al., 2015) and increasing the chances of specialist extinction (Heino et al., 2013), decrease in beta diversity (Chase, 2007), and dominance of tolerant or resistant species (Maddock, 1999; Morales et al., 2012; among others).

Considering the differences in hydrology and anthropic disturbance history between the Ascotán and Carcote salt flats in the Dry Puna ecoregion, the aim of this study is to compare the diatom community assembly by guild between the salt flats in order to respond to the following questions: are there local differences in the community structure of benthic diatoms in Andean salt flats or at the level of functional groups (diatom guilds)?; are facilitation associations between diatom guilds promoted under stress environmental conditions?; could differences in the function or structure of the diatom communities be associated with anthropic perturbations, as those produced by intensive mining?; and which mechanism (turnover or nestedness) mainly explains the observed beta diversity?

\section{MATERIALS AND METHODS}

\section{Study Area}

This study was carried out in two salt flats located in the southern area of the Altiplano: Ascotán $\left(21^{\circ} 35^{\prime} 0^{\prime \prime} \mathrm{S}, 68^{\circ} 15^{\prime} 0^{\prime \prime} \mathrm{W}\right)$ and Carcote $\left(21^{\circ} 22^{\prime} 36^{\prime \prime} \mathrm{S}, 68^{\circ} 20^{\prime} 55^{\prime \prime} \mathrm{W}\right)$. Both salt flats are located at $3,700 \mathrm{~m}$ a.s.l. in the Antofagasta region, northern Chile. Both salt flats are fed by springs that discharge groundwater from the nearby volcanic aquifers, mainly recharged from seasonal rainfall, snowmelt, and sporadic rainfall events, and through the drainage network that provides water and sediments by hydrological erosion, triggering the development of alluvial fans. The Ascotán and Carcote basins are connected hydrogeologically and, because of their spatial proximity, are exposed to the same climatic conditions, yet they exhibit local, distinct physicochemical behaviors (Flores-Varas et al., 2021). An additional difference between these basins is the degree of anthropic disturbance, as Ascotán has been exploited for boron extraction since 1883 (Chong et al., 2010), while Carcote has not been subject to disturbance by industrial extraction.

According to Luebert and Pliscoff (2006), these salt flats belong to the tropical-xeric bioclimate, characterized by its aridity. The evaporitic basins in this zone are mainly endorheic, which leads to the formation of salt flats (Marazuela et al., 2019).

The basins of both salt flats are adjacent, $4 \mathrm{~km}$ apart along their nearest edges. The Ascotán salt flat has the largest extension $\left(243 \mathrm{~km}^{2}\right)$ compared to Carcote $\left(108 \mathrm{~km}^{2}\right)$. While Ascotán has been exploited for boron extraction since 1883 (Chong et al.,
2010), Carcote has not been exposed to extractive anthropogenic disturbance.

To capture all habitat variability, 17 sampling points were chosen; nine in Ascotán and eight in Carcote (see Flores-Varas et al., 2021) (Figure 1).

\section{Sample Collection}

Samples were collected in the summer season, during January 2019. Sediment and water samples were collected from each sampling point for both chemical and diatom analyses. Sediment samples (200-500 g) were obtained from each sampling site by collecting the upper layer of sediment using a plastic dredger. Each sample was preserved with 30\% ethanol, stored at $4^{\circ} \mathrm{C}$, and transported to the laboratory for analysis. These samples were analyzed for diatoms, the content of the elements $\mathrm{C}, \mathrm{N}$, and $\mathrm{P}$, and granulometric analysis. Subsamples for $\mathrm{C}$ and $\mathrm{N}$ content were subjected to dry combustion $\left(1,100^{\circ} \mathrm{C}\right.$ nominal). $\mathrm{N}$ was subsequently detected by thermal conductivity and $\mathrm{C}$ by nondispersive infrared spectrophotometry, using a CNS elemental analyzer (TruMac CNS Macro Analyzer, LECO) in the Soils Ecology Laboratory of the Faculty of Forest Sciences and Nature Conservation, Universidad de Chile. Sediment subsamples were subjected to the ignition method to determine the total P content (Saunders and Williams, 1955). The samples were ignited at $550^{\circ} \mathrm{C}$ for $2-3 \mathrm{~h}$ using $1 \mathrm{~N}$ sulfuric acid and then shaken for $16.5 \mathrm{~h}$ at room temperature. Finally, the concentration of $\mathrm{P}$ was measured according to the methodology of Murphy and Riley (1962).

For granulometric characterization, grain sizes were lumped into three categories, sand, silt, and clay, according to the Udden-Wentworth scale (Tucker, 2009). Three samples (C2, C4, and A2) were analyzed in the Department of Geological Sciences of the Universidad Católica del Norte (Chile) using Tyler meshes (\#10 to \#400) with rotopercussion equipment that allows displacement of the sediment between each mesh. The data were processed using Grapher (v. 4.00) software. The other 13 samples, those with a finer grain, were analyzed by laser diffraction of particle distribution (range $20 \mathrm{~nm}-2 \mathrm{~mm}$ ) using a MasterSIZER 2000 in the Department of Geology of the Universidad de Chile. Data processing was carried out using Hydro2000 software.

For the water analysis, three 1- L samples were obtained from each sampling site and preserved for laboratory analyses. Also, at each sampling site, the physical and chemical parameters of the water column were measured in situ (temperature, salinity, conductivity, redox potential ORP, dissolved oxygen, and $\mathrm{pH}$ ) using a multiparameter device (Hanna HI98194).

Surface water samples were collected for posterior elemental concentration analysis in eight samples from Ascotán and six samples from Carcote. The water samples were analyzed by ICPOES (OPTIMA 8300 HIDRUROS; PerkinElmer). All the material other than the tubes used in the equipment was washed by immersion $(5 \mathrm{~min})$ in a solution of water and nitric acid (10: $1)$, cleaned with distilled water, and oven-dried at $65 \pm 10^{\circ} \mathrm{C}$. Liquid samples were filtered to remove suspended particles. The measurements were calibrated using a multielement standard solution (composed of $\mathrm{Na}, \mathrm{K}, \mathrm{Ca}, \mathrm{Mg}, \mathrm{B}, \mathrm{Cr}, \mathrm{Fe}, \mathrm{Ni}, \mathrm{Cu}, \mathrm{Zn}, \mathrm{Cd}$, $\mathrm{Pb}, \mathrm{Al}, \mathrm{Co}, \mathrm{Tl}, \mathrm{S}, \mathrm{P}, \mathrm{As}, \mathrm{Mo}, \mathrm{Se}, \mathrm{Sb}, \mathrm{Ti}, \mathrm{Be}, \mathrm{Bi}, \mathrm{V}, \mathrm{Sr}, \mathrm{Li}, \mathrm{Rb}$, and 


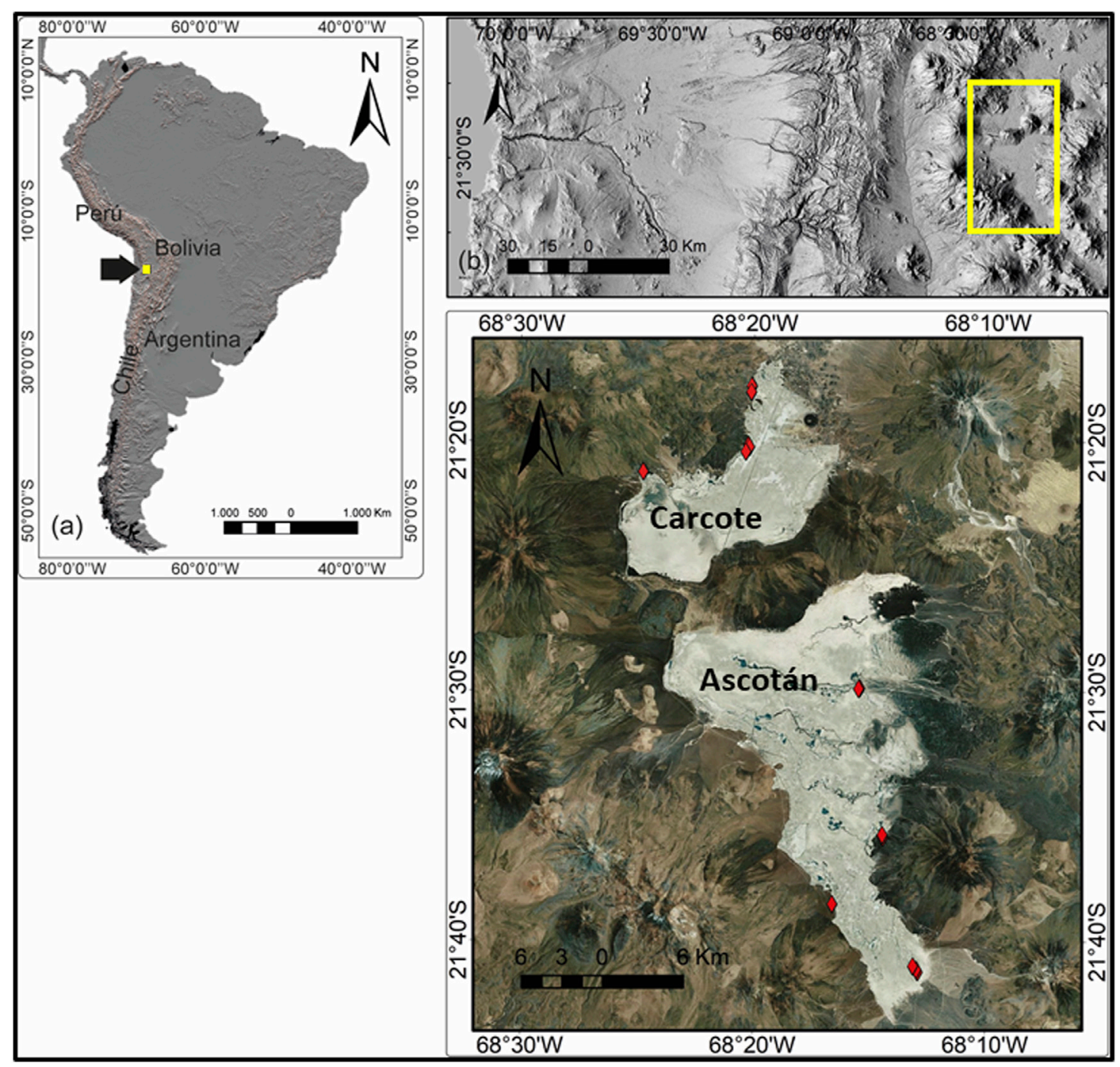

FIGURE 1 | Location of the Carcote and Ascotán salt flats in the Altiplano area in Chile and sampling sites distributed therein. The red points represent the specific sampling areas within each salt flat, there being nine sampling sites in the Ascotán and eight sites in the Carcote salt flat.

$\mathrm{Mn})$ at different concentrations diluted in ultrapure water. The calibration curve for the different elements was constructed according to the concentrations of these multielement calibration solutions (see Supplementary Material).

The assay control was performed by adding a known concentration of the analyte to a dilution of one of the samples measured in the analytical series. On $5 \mathrm{ml}$ of the measured sample dilution, we added $5 \mathrm{ml}$ of the highest concentration standard. The result obtained from this enrichment must have a value of $\pm 10 \%$ of the theoretical value. In the same way, a blank control was carried out, whose value did not present a final concentration higher than the detection limit, which is $1 / 3$ the limit of quantification for each of the elements reported. Finally, an acceptance /rejection criterion was established for the measurements performed in duplicate: The maximum accepted difference between duplicates was between 90 and $110 \%$. The result was the average of the two duplicates. When the results obtained do not meet the established acceptance criteria, a new repetition of the corresponding test method was carried out.

\section{Diatom Diversity and Abundance}

From each wet sediment sample, a 10-ml subsample was taken and prepared for diatom taxonomic analysis. The sediment samples were treated with $37 \% \mathrm{HCl}$ for $15 \mathrm{~min}$ to dissolve carbonates and $30 \% \mathrm{H}_{2} \mathrm{O}_{2}$ to digest organic matter to facilitate the view of the taxonomic features of the frustules. Last, the samples were kept in a thermoregulated bath at $80^{\circ} \mathrm{C}$ for $30 \mathrm{~min}$ following the study by Díaz et al. (2016).

Subsequently, digested samples were analyzed using an optical microscope to determine the concentration of valves. As recommended by Díaz et al. (2016), samples were diluted until frustules were distinguishable from one another without overlap for improved identification and an accurate count at a 
TABLE 1 | Diatom guild classification according to Passy (2007).

\section{Guild}

Low profile

High profile

Motile
Characteristics

Species of short stature, either prostrate, adnate, or erect, along with solitary-centric and slow-moving species. Species of tall stature; erect, filamentous, branched, chain-forming, tube-forming, stalked, and colonial-centric species. Species with active movement. magnification of $\times 40$. After that, permanent slides were mounted with Naphrax as described by Battarbee (1986). Permanent samples were observed using a Zeiss microscope at $\times 100$, and microphotographs were taken using an Olympus camera attached to the microscope. Valves were identified at the species or subspecies level following Krammer and LangeBertalot (1986-1991). Species richness was estimated from diatom counts. Cell densities (abundance) were determined by converting the numbers of cells counted per square centimeter of the substrate; abundance was calculated using the formula proposed by Battarbee (1986). The diversity index of Shannon's exponential (Jost, 2006) was used. This estimation recommends that the Shannon entropy be converted to its numeric equivalent by taking its exponential (MacArthur, 1965)

\section{Diatom Guild Classification}

Diatoms were categorized into guilds following the classification proposed by Passy (2007). Thus, diatom species were classified into a guild depending on their use of space and microhabitat (see Table 1; Supplementary Material). Shannon's exponential (Jost, 2006) and species richness were calculated for both the guild and sample to compare between salt flats and among guilds.

\section{Statistical Analysis}

To detect statistical differences in diatom abundance, richness, and Shannon's exponential between salt flats and among guilds, generalized linear models (GLMs) with a gamma distribution and the inverse link function were used.

To compare the specific composition of the assemblages, a nonmetric multidimensional scaling (NMDS) was performed with species abundance as a dependent variable and guilds and salt flats as grouping variables. In this analysis, the chemical composition of the water was used as an environmental variable. It is important to note that ionic concentrations were not available for all sites; the analysis was performed for eight sites in Ascotán and six sites in Carcote.

Additionally, ion concentrations $\left(\mathrm{K}, \mathrm{Cl}, \mathrm{Na}, \mathrm{HCO}_{3}, \mathrm{Mg}, \mathrm{Ca}\right.$, $\mathrm{SiO}_{2}, \mathrm{Co}$, and $\mathrm{B}$ ) in water were compared between salt flats using Kruskal-Wallis tests.

To assess the similarity (or dissimilarity) of diatom communities among salt flats and the nestedness among them, the Jaccard index was calculated based on the presence/absence data of the different species by salt flat. Then, from the Jaccard index, turnover and nestedness were used to estimate the beta diversity for the different guilds across salt flats. The beta diversity was partitioned into contributions by spatial turnover and nestedness, as in the study by Baselga (2010). The Jaccard index was calculated for the presence/absence data of the different species at each salt flat and was used to obtain the components of beta diversity (turnover and nestedness).
Diversity indexes were estimated using the vegan package (version 2.5-6) (Oksanen et al., 2019), and beta diversity was calculated using the betapart package (version 1.5.2) (Baselga et al., 2020), and both libraries were implemented in the $\mathrm{R}$ environment (version 3.6.2) (R Core Team, 2019).

\section{RESULTS}

\section{Site and Guild Differences}

Diatom abundance showed statistical significance in the interaction between salt flats and guilds (GLM $p<0.001$; see Supplementary Material). The Carcote salt flat had a statistically higher abundance of diatom species in all the guilds than the Ascotán salt flat (Figure 2A). In the case of richness, statistical differences were observed between the salt flat $(p=0.001)$ and the guild $(p<0.001)$ as main factors (Figure $2 \mathbf{B}$ ), with higher values of richness observed in Carcote $($ mean $=40.03$; $\mathrm{SD}=6.97)$ than in Ascotán (mean $=30.8 ; \mathrm{SD}=8 \pm 4.71)$. Also, there was a higher richness of motile diatoms (mean $=23.78)$ than of high-profile $($ mean $=4.44)$ and low-profile $($ mean $=11.16)$ diatoms at the Carcote salt flat. The exponential Shannon diversity index was statistically different between salt flats $(p=0.04497)$ and guilds $(p<0.001)$, and greater values by guild were observed in Carcote than in Ascotán (Figure 2C).

The largest diatom abundance was found in Carcote, although the same decreasing pattern was observed in the high-profile, low-profile, and motile guilds for both salt flats. Low-profile diatoms from Carcote had a higher abundance than motile diatoms from Ascotán, showing the interaction between salt flats and the guild type (Figure 2A).

An inverse pattern of that of abundance per guild was observed in richness (Figure 2B) and Shannon's index exponential (Figure 2C), with increasing values from highprofile to motile guilds. Significant differences were observed in richness $(p=0.003)$ and Shannon's index exponential $(p=0.044)$ between salt flats and between richness per guild $(p>>0.05)$ and Shannon's index exponential by guild $(p>>0.05)$ but not for their interactions $(p=0.9)$. The highest richness belonged to the motile guild from Carcote, followed by the motile guild from Ascotán (Figure 2B).

Diversity patterns observed by guild were conserved among salt flats, although they were varied in magnitude (see Supplementary Material).

\section{Assemblage Composition (NMDS)}

First, samples from Ascotán had more dispersed data in the first two dimensions of the analysis (Figures 3A,B). Second, data from Carcote were mostly contained in the space of samples occupied 

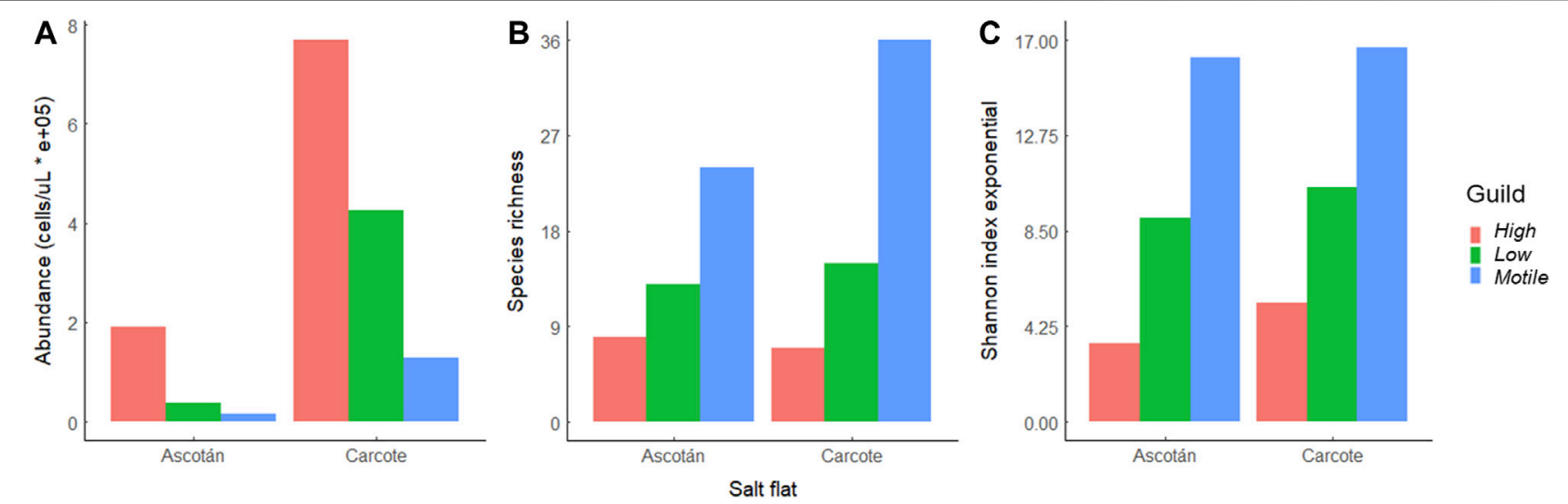

FIGURE 2 | (A) Abundance of diatoms. (B) Species richness. (C) Shannon diversity entropy index for high-profile, low-profile, and motile guilds present in the Ascotán and Carcote salt flats.
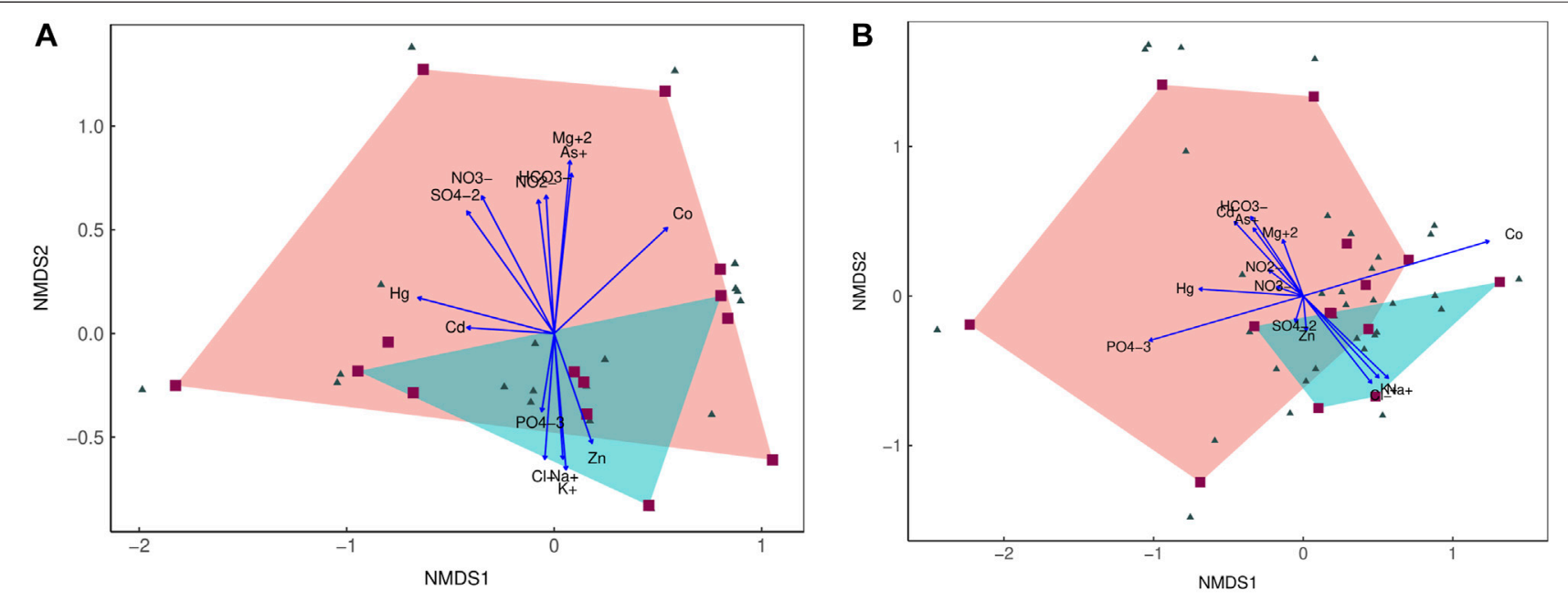

C

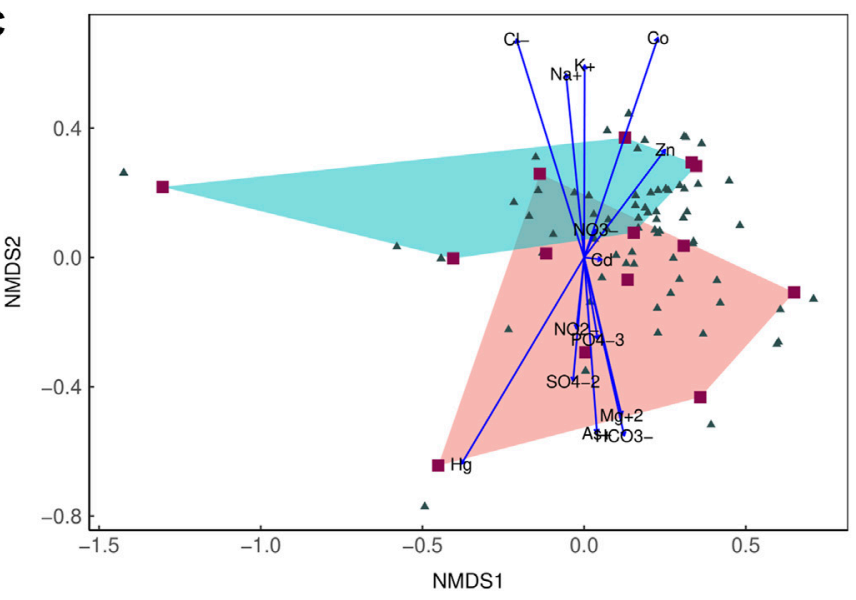

Salt flat

Carcote

FIGURE 3 | NMDS analysis with environment ionic water column concentration for (A) high-profile, (B) low-profile, and (C) motile guilds; polygons represent the Ascotán (red) and Carcote (blue) salt flats. 
by Ascotán, probably because Carcote has a smaller area than Ascotán. This result was observed for high-profile (2D stress 0.128 , Figure 3A), low-profile (2D stress 0.159 , Figure $3 B$ ), and motile species ( $2 \mathrm{D}$ stress 0.133 , Figure $3 \mathrm{C}$ ). In motile species, the graphic distance between sites, or the area of the polygons, is smaller (see the axes of Figure 3C), indicating a higher similarity in the assemblages of both salars for this group of diatoms than for the high- and low-profile diatoms (see Supplementary Material). Additionally, ANOSIM suggests that differences in species composition between the salt flats for high-profile, low-profile, and motile guilds were not statistically significant, but the nearest value to zero indicates a similarity in community composition between the salt flats (high profile: ANOSIM statistic $R=-0.043$; low profile: ANOSIM statistic $R=-0.057$; motile: ANOSIM statistic $R=$ $-0.121)$.

\section{Environmental Variables}

From the same NMDS, the ionic composition of $\mathrm{Cl}, \mathrm{K}$, and $\mathrm{Na}$ showed a clear association with the three guilds in the Carcote salt flat, while $\mathrm{HCO}_{3}, \mathrm{Mg}, \mathrm{Hg}$, As, $\mathrm{B}$, and Co ions were associated with Ascotán. These polygons are overlaid, indicating an unclear differentiation in communities from each salt flat, especially for high-profile species, suggesting different configurations by analyzed guild (Figure 3 ).

Although high- and low-profile guilds were the greatest of the Ascotán polygon, the motile species' salt flat polygons were similar in size, with small overlap, which indicates that for any community, guilds were not completely different between the salt flats (it is important to note that Ascotán has a higher number of sampling sites).

The predominance of ions was significantly different between salt flats. The major ions found in the Carcote salt flat were $\mathrm{Cl}, \mathrm{K}$, $\mathrm{Na}, \mathrm{Ca}$, and $\mathrm{SiO}_{2}$ (Kruskal-Wallis chi-squared $=9.6, \mathrm{df}=1, p<$ 0.01), while ionic values were higher in Ascotán than in Carcote, and significantly higher were $\mathrm{HCO}_{3}, \mathrm{Mg}, \mathrm{As}, \mathrm{NO}_{2}, \mathrm{~B}$ (Kruskal-Wallis chi-squared $=9.6, \mathrm{df}=1, p<0.01$ ), Co (Kruskal-Wallis chi-squared $=5.4, \mathrm{df}=1, p<0.05$ ), and $\mathrm{Hg}$ (Kruskal-Wallis chi-squared 8.07, $\mathrm{df}=1, p<0.01$ ). The motile guild was significantly correlated with several ions $(\mathrm{Cl}, \mathrm{K}, \mathrm{Ca}, \mathrm{Mg}$, $\mathrm{SiO}_{2}, \mathrm{Co}$, and $\mathrm{Zn} ; p<0.05$ ), while the low-profile guild was correlated with $\mathrm{Zn}$ and $\mathrm{PO}_{4}$ and the high-profile guild, uniquely, with $\mathrm{Hg}(p<0.05)$. The granulometry significantly and uniquely determined motile guild communities (NMDS analysis). The major component in Ascotán was sand and in Carcote, silt (Kruskal-Wallis chi-squared $=3.8347 \mathrm{df}=1, p=0.05$ ). Although the clay content was higher in Carcote, this difference was not significant.

The sediment analysis did not detect significant $\mathrm{N}, \mathrm{C}$, and $\mathrm{P}$ content differences between salt flats. The low-profile diatoms were associated with $\mathrm{C}$ and $\mathrm{P}$ variables (in NMDS) but are not significant. Nevertheless, in the ionic analysis, $\mathrm{PO}_{4}$ was associated significantly with the low-profile guild. This analysis also showed a relationship between dissolved $\mathrm{O}_{2}$ and the low-profile guild, where there is more variation in measures developed at Ascotán. Carcote sampling sites had high concentrations of dissolved $\mathrm{O}_{2}$ with little variation between sites.
TABLE 2 | Turnover and nestedness partition of the Jaccard index by guild.

\begin{tabular}{lccc}
\hline Guild & Total Jaccard similarity & Spatial turnover & Nestedness \\
\hline High & 0.565 & 0.375 & 0.190 \\
Low & 0.488 & 0.462 & 0.026 \\
Motile & 0.489 & 0.460 & 0.029 \\
\hline
\end{tabular}

\section{Guild Turnover}

Turnover was the greatest component of the beta diversity of all guilds (Table 2). Greater similarities were observed between communities for the high-profile guild. The other guilds showed more dissimilarity between the salt flats, and in these cases, the spatial turnover was the main driver of beta diversity.

Finally, the high-profile species had the highest value for both total similarity and nestedness, and the nestedness represents $33.6 \%$ in relation to the total beta diversity. This result suggests that the high-profile guild was more nested than the motile and the low-profile guilds, in which the turnover represented a major proportion. In other words, the species community replacement of motile and low-profile guilds was higher and almost completely related to the species replacement (94.1 and $94.7 \%$ of beta diversity, respectively, are explained by turnover).

\section{DISCUSSION}

\section{Differences Between Salt Flat Communities and Their Relationship to the Anthropic Effect}

The Ascotán and Carcote salt flats are geographically close and despite their proximity and sharing of geological evolution and climatic stories, their ecological structures are different at the diatom community level. The results of this study clearly show the differences between the salt flats in richness, diversity, and abundance of diatoms, functionally categorized by guild. Higher values were observed in Carcote than in the Ascotán salt flat, the latter being the disturbed system.

From the functional perspective, the largest abundance for all diatom guilds was found in Carcote (Figure 2A), suggesting that this system supports higher primary productivity. This condition could be related to lower anthropic impact than that observed in the Ascotán salt flat. Other studies have shown similar results associated with an increase in artificial (human) modification (Bona et al., 2008) in terms of the direct polymetallic presence in the water (Morin et al., 2008) or surrounding high volumes of mine waste (Luís et al., 2009). Overall, diatom communities showed sensitivity to changes in water quality or disturbance of natural environments, even those associated with specific environments.

Among the different guilds analyzed, high-profile species showed higher diatom abundances (Figure 2A) and the lowest values of species richness and diversity compared to the lowprofile and motile species (Figures 2B,C). High-profile species were also dominant in the community assembly, which could be explained by the low flow conditions, since these species lack the 
ability to resist high flows of water (Passy 2007). On the other hand, motile guild species showed the largest richness and exponential Shannon diversity index, explained by the diversity of species from the genera Nitzschia and Navicula (Supplementary Material). Species from both genera have been previously associated with thermal systems in northern Chile (Angel et al., 2018) and in other thermal water springs in the world (Lai et al., 2019), which could explain their high presence in these salt flats that recharge groundwater from surrounding volcanoes (including the Ollagüe volcano).

\section{Community Composition and Similarity}

The overlap of the diatom community guilds in some sites (NMDS results, Figure 3) shows similarity between the community assemblages of the salt flats, which may be explained by their proximity and climatic, geomorphological, and other regional shared histories (Flores-Varas et al., 2021). The main differences could be related to the anthropic disturbances present in Ascotán, where there has been a historical water and brine extraction (Servicio Nacional de Geología y Minería, 2017), producing an additional hydric stress (Acosta and Custodio, 2008) that would decrease the ecological richness of the system (Marazuela et al., 2020). Additionally, natural differences appear among the basins, namely, local conditions on a smaller scale, such as ionic concentrations, which could be associated with the typically high concentration of metals and metalloids, such as $\mathrm{Pb}, \mathrm{Hg}$, $B$, and As, in Ascotán.

High-profile diatoms were more similar and motile diatoms more dissimilar between salt flats (Table 2). This greater similarity found for the high-profile guild among the two salt flats (Table 2) must be analyzed along with the lower species richness (Figure 2B) and higher abundance (Figure 2A) found for this guild. Being that there is a smaller number of species in this guild and greater abundance, a few species dominate the assemblage, probably the most adapted to these environmental particularities. Considering both salt flats, the greater proportion of beta diversity explained by nestedness for the high-profile guild (33.6\%) also points to the highest adeptness of the few species present, thus not increasing the gamma diversity of the system. This indicates that for this guild, the general extreme environmental conditions shared by both salt flats determine the beta diversity, as was found by Benito et al. (2018a). Jamoneau et al. (2018) studied patterns that affected the beta diversity of diatoms along a stream watercourse and identified different mechanisms associated with guild diversity. Mass effect is a homogenization mechanism of communities that decreases beta diversity by allowing species to persist in unfavorable habitats due to high levels of dispersal from source locations (Shmida and Wilson 1985), where environmental conditions enable high population densities. Mass effect differentially affected the motile diatom guilds, while the low-profile species were primarily influenced by environmental conditions in the study conducted by Jamoneau et al. (2018). In our results, the low water flow has a low spatial influence, the low connectivity by the heterogeneity of the environment suggests a major influence of environmental filtering because we evaluated similarity in different environments, where the watercourse is minimal, and the mass effect is not necessarily associated with directional water transport.

\section{Differences in the Environment Resulting From Natural Causes and Anthropic Activity}

We identify environmental habitat characteristics associated with the distribution pattern of diatom guilds, which are determinants to describe the different environments. In multiple ways, those determinants can generate an interactive effect between several factors.

First, the hydrology and water availability in the Andean salt flats can modify habitat quality through natural or anthropic disturbances. Reduction of the water basin surface, recorded for other highly mined Andean salt flats, could also negatively impact algal beta and gamma diversity. Ponds with lower energy, evidenced by low flow and finer grain sediments, host a specific algal flora sensitive to flow disturbance but resistant to burial, such as low-profile algae and motile diatoms (Passy and Blanchet 2007). Species from high-profile guilds would be better adapted to high nutrient concentrations and low current velocities (Passy, 2007; Rimet and Bouchez, 2011), while hydrological disturbances result in a greater abundance of lowprofile species (Salmaso et al., 2019). Considering the very low flow of water from the Ascotán and Carcote springs and that surface water transport depends on the intensity of the wind, this could explain the highest abundance of high-profile guilds in salt flat environments, in addition to a greater contribution of nutrients in Carcote, which would allow for significantly higher abundances.

Second, the specific geochemical conditions of each salt flat and the ion concentrations in their water could determine the availability of habitats for the different diatom guilds. Water availability influences nutrient concentration, and chemical changes caused by high concentrations of nitrate and total phosphorus cause higher abundance and species richness of motile species (Salmaso et al., 2019). In a previous study, Soininen et al. (2016) explained that total P has a weaker relationship with the diatom composition than other variables. Nevertheless, low-profile species are bound to the substrate and are therefore more limited by the availability of nutrients such as $\mathrm{P}$. In our study, $\mathrm{P}$ was associated with the low-profile guild in Ascotán. Given the high variability within and between salt flats, relative concentrations of $\mathrm{P}$ could be a determining factor in the distribution of this guild.

Water chemistry and salinity have been indicated as the most influential environmental predictors of the beta diversity of benthic invertebrates, and they have been associated with strong turnover (Menegotto et al., 2019). We detected a substantial difference in salinity between Carcote and Ascotán. The former showed a salinity ranging from 25 to $30\left(\mathrm{~g} \mathrm{~L}^{-1}\right)$ and the latter, from 1.31 to $5.22\left(\mathrm{~g} \mathrm{~L}^{-1}\right)$ (Flores-Varas et al., 2021). Moreover, the brine composition was also different; in Carcote, the major ions were associated with the composition of evaporitic environments in playa lakes, and in Ascotán, the metallic ions were dominant. Among the quantified metals, Co was a 
significant variable for motile and low-profile guilds. Co is associated with the physiological response of diatoms, and high Co concentrations inhibit algal growth, with speciesspecific responses (El-Sheekh et al., 2003). In Ascotán (mean cobalt $=1.7 \mathrm{ppm})$, the values were greater than they were in Carcote $($ mean cobalt $=1 \mathrm{ppm})$ and could be associated with the observed greater abundance, species richness, and diversity for this salt flat. Metal concentrations in the Altiplano water bodies are mainly of natural origin, although they can be partially contributed by mining activities (Tapia and Audry, 2013; Tapia et al., 2019). Conversely, $\mathrm{Hg}$ and $\mathrm{Pb}$ ion concentrations are mainly explained by the anthropic influence in these salt flats. These metals, especially $\mathrm{Hg}$, were higher in Ascotán and have been previously associated with copper mining activity, exerting harmful effects on the environment (see Hsu-Kim et al., 2018). The presence of frustules of teratological forms, found uniquely in Ascotán, is another antecedent related to higher non-natural metal concentrations in this salt flat (Flores-Varas et al., 2021). Studies have shown that metal pollution of lotic systems driven by anthropic activities has promoted the dominance of small adnate species and exhibited anomalous proportions of deformed individuals (Morin et al., 2008).

Finally, sediment composition and grain size also significantly affected the creation of habitats for the motile guild. In Ascotán, there was a larger proportion of coarse grain size, as sand, than at Carcote. Coarse-grained sediments and sand size were associated with a larger input of detrital material of allochthonous origin through water inflow to the basin, which may be associated with seasonal wet events. Grain characteristics may be associated with the lowest abundance, diversity, and richness of motile diatoms present in Ascotán. In contrast, Carcote, dominated by finergrained sediments, such as silt and clay, is associated with precipitation of mainly authigenic material (Aránguiz-Acuña et al., 2020; Flores-Varas et al., 2021; García-Sanz et al., 2021), on which unattached diatoms are more likely to settle (Smucker and Vis, 2010). It has been suggested that depositional habitats are advantageous for motile diatoms because their raphes allow them to avoid being smothered by sediments (Stevenson and Bahls, 1999).

\section{Beta Diversity Implications for Conservation}

Turnover, rather than nestedness, had a greater effect on the spatial distribution of communities in the salt flats. It is expected that system heterogeneity will minimize nestedness to some degree (Wright and Reeves, 1992). The diatom communities are determined by species sorting mechanisms. The hardness of the Puna environment constrains the dispersion opportunities, and the communities are mainly structured by environmental filters, which promotes strong turnover patterns (Jamoneau et al., 2018). Species turnover is consistently more strongly related to geographic distance than to change in climate conditions due to environmental sorting or spatial and historical constraints (Qian et al., 2005). The turnover, or species replacement, implies the simultaneous gain and loss of species due to environmental filtering, competition, and historical events (Leprieur et al., 2011). For diatom communities, environmental filtering seems to play an important role in structuring metacommunities irrespective of the watercourse position. Disturbance decreases beta diversity, and since the anthropic disturbance, could represent an additional environmental filter, affecting beta diversity, nestedness, and turnover (Hill et al., 2017). Additionally, for the systems studied by Hill et al. (2017), turnover was the greatest contributor to beta diversity. The major percentage of the nesting mechanism in the high-profile guild, in comparison to the other guilds, may be explained by the fact that the species of this guild are sessile and associated to macrophytes (Passy 2007), for which they are affected by human water flux modifications (personal observation in the sampling). The nesting component of beta diversity is related to the anthropic effect on the communities, by the filtering of specialist species (Gutiérrez-Cánovas et al., 2013).

Species turnover, identified as the main driver of the diatom community structure in Ascotán and Carcote, makes a regional conservation approach imperative, focused on multiple sites including contiguous basins (Wright and Reeves, 1992). In this sense, we propose that an integrated conservation plan is needed, considering the two salt flats' biodiversity.

\section{Final Remarks}

Our results highlight the relevance of the spatial heterogeneity observed in the studied Andean Altiplano salt flats as a promoter of different habitats, necessary to support diatom diversity. Although the guilds used in this work adequately explained the community indices and distribution of diatom species, we did not include planktonic forms because the sampling was focused on the sediment matrix. Although the water column did not exceed $15 \mathrm{~cm}$ in depth in almost all the sampling points, this guild could be explored in future studies. Future works should also consider temporal variations, given that summer rains drive the seasonal water supply. Nonperiodical climatic events, especially possible climate change scenarios or water depletion through extensive use in the mining industry, also require examination. However, we develop an extensive sampling, with numerous environmental variables measured in each sampling point. For these salt flats, there are no previous works which consider, in addition to biological sampling, the sediment characteristics and ionic water column composition, and therefore, our results open new opportunities to deepen future scientific questions integrating biogeochemical approaches.

The main mining activity in Chile is concentrated within the Atacama Desert and the Altiplano, and it is expected to increase due to the development of new projects and the expansion of existing ones. Ascotán and Carcote, along with other salt flats, are inside the core of "the lithium triangle," extending to the Bolivian and Argentine Altiplano. The increase in mining operations, needed to satisfy the increasing world demand for alternative energy, will cause additional threats to biodiversity (Sonter et al., 2020) and will increase water demand. Estimations of the water scarcity index show that the highest values occur in the Antofagasta region (Aitken et al., 2016). Moreover, in Chile, the water rights are commercialized in a "water market," and the aquatic ecosystems do not have integrative environmental protection. Water level and flow modifications alter the 
physical environment and can generate unknown ecological consequences for these high-altitude environments. The application of our results to knowledge of principal primary producers of the Carcote and Ascotán salt flats is useful with regard to conservation due to the unique evolutionary scenario in which it is possible to study the adaptiveness to changing environmental pressures. Finally, the cultural significance of these salt flats for the Quechua community of Ollagüe should be considered in future studies in which the value of ecosystems can be considered in the context of mining impacts on the water ecology and the economic or ancient cultural value.

\section{DATA AVAILABILITY STATEMENT}

The original contributions presented in the study are included in the article/Supplementary Material; further inquiries can be directed to the corresponding author/s.

\section{AUTHOR CONTRIBUTIONS}

IH-F: principal author for the text and responsible for editing the whole manuscript, methodology, sample treatment, validation, formal analysis, project administration, conceptualization, investigation, resources, and funding acquisition. CL-A: sample

\section{REFERENCES}

Acosta, O., and Custodio, E. (2008). Impactos ambientales de las extracciones de agua subterránea en el Salar del Huasco (norte de Chile). Boletín Geológico y Minero 119, 33-50.

Aguilar, P., Acosta, E., Dorador, C., and Sommaruga, R. (2016). Large Differences in Bacterial Community Composition Among Three Nearby Extreme Waterbodies of the High Andean Plateau. Front. Microbiol. 7, 976. doi:10.3389/fmicb.2016.00976

Ahumada, M., Aguirre, F., Contreras, M., and Figueroa, A. (2011). Guía para la conservación y seguimiento ambiental de humedales andinos. 50. Available at: http://www.sinia.cl/1292/articles-53554_guiaConsSeguimientoHumedales2011.pdf (Accessed October 5, 2020).

Aitken, D., Rivera, D., Godoy-Faúndez, A., and Holzapfel, E. (2016). Water Scarcity and the Impact of the Mining and Agricultural Sectors in Chile. Sustainability 8 (2), 128. doi: $10.3390 /$ su8020128

Albarracín, V. H., Dib, J. R., Ordoñez, O. F., and Farias, M. E. (2011). “A Harsh Life to Indigenous Proteobacteria at the Andean Mountains: Microbial Diversity and Resistance Mechanisms towards Extreme Conditions," in Proteobacteria: Phylogeny, Metabolic Diversity and Ecological Effects. Editor M. L. Sezenna (New York, NY: Nova Science Publishers, Inc.), 91-131.

Albarracín, V. H., Gärtner, W., and Farias, M. E. (2016). Forged Under the Sun: Life and Art of Extremophiles from Andean Lakes. Photochem. Photobiol. 92 (1), 14-28. doi:10.1111/php.12555

Angel, A., Vila, I., Díaz, C., Molina, X., and Sepúlveda, P. (2018). Geothermal Diatoms: Seasonal Variability in the El Tatio Geothermal Field (Altiplano, Chile). AiM 08, 211-234. doi:10.4236/aim.2018.83015

Aránguiz-Acuña, A., Luque, J. A., Pizarro, H., Cerda, M., Heine-Fuster, I., Valdés, J., et al. (2020). Aquatic Community Structure as Sentinel of Recent Environmental Changes Unraveled from Lake Sedimentary Records from the Atacama Desert, Chile. PLoS One 15 (2), e0229453. doi:10.1371/ journal.pone.0229453

Baselga, A., Orme, D., Villeger, S., De Bortoli, J., Leprieur, F., and Logez, M. (2020). Betapart: Partitioning Beta Diversity into Turnover and Nestedness treatment and analysis, species identification and classification, formal analysis, and investigation. AA-A: conceptualization, methodology, validation, investigation, resources, writing - original draft, writing — review and editing, supervision, project administration, and funding acquisition. DV: methodology, validation, investigation, resources, writing, review, and editing.

\section{FUNDING}

This study was supported by authorities of I. Municipalidad de Ollagüe. IH-F thanks the National Agency for Research and Development (ANID)/Scholarship Program/Doctorado Nacional 2015 and Gastos Operacionales-21151214. AA-A thanks UTA-Mayor 4724-21. DV acknowledges the financial support of the Chilean Millennium Initiative grant ESMOI. Authors thank the Geology Department, Universidad de Chile, and Fondequip-Conicyt EQM160084 elemental analyzer CNS from Universidad de Chile.

\section{SUPPLEMENTARY MATERIAL}

The Supplementary Material for this article can be found online at: https://www.frontiersin.org/articles/10.3389/fenvs.2021.701970/ full\#supplementary-material

Components. R package version 1.5.2. Available at: https:/CRAN.R-project. org/package=betapart (Accessed October 5, 2020).

Baselga, A. (2010). Partitioning the Turnover and Nestedness Components of Beta Diversity. Glob. Ecol. Biogeogr. 19 (1), 134-143. doi:10.1111/j.1466-8238.2009.00490.x

Battarbee, R. W. (1986). "Diatom Analysis," in Handbook of 708 Holocene Palaeoecology and Palaeohydrology. Editor B. E. Berglund (Chichester: Wiley), 527-570.

Benito, X., Fritz, S. C., Steinitz-Kannan, M., Tapia, P. M., Kelly, M. A., and Lowell, T. V. (2018a). Geo-climatic Factors Drive Diatom Community Distribution in Tropical South American Freshwaters. J. Ecol. 106 (4), 1660-1672. doi:10.1111/ 1365-2745.12934

Benito, X., Fritz, S. C., Steinitz-Kannan, M., Vélez, M. I., and McGlue, M. M. (2018b). Lake Regionalization and Diatom Metacommunity Structuring in Tropical South America. Ecol. Evol. 8 (16), 7865-7878. doi:10.1002/ ece 3.4305

Bona, F., Falasco, E., Fenoglio, S., Iorio, L., and Badino, G. (2008). Response of Macroinvertebrate and Diatom Communities to Human-Induced Physical Alteration in Mountain Streams. River Res. Applic. 24 (8), 1068-1081. doi: $10.1002 /$ rra.1110

Cardoso, P., Rigal, F., Borges, P. A. V., and Carvalho, J. C. (2014). A New Frontier in Biodiversity Inventory: A Proposal for Estimators of Phylogenetic and Functional Diversity. Methods Ecol. Evol. 5 (5), 452-461. doi:10.1111/2041210X.12173

Chase, J. M. (2007). Drought Mediates the Importance of Stochastic Community Assembly. Proc. Natl. Acad. Sci. 104 (44), 17430-17434. doi:10.1073/pnas.0704350104

Chong, G., Pueyo, J. J., and Demergasso, C. (2010). The Borate Deposits in Chile. Andean Geology. 27 (1), 99-119. doi:10.5027/andgeoV27n1-a07

Collado, G. A., and Méndez, M. A. (2012). Phylogenetic Relationships and Taxonomy of Altiplano Populations of Biomphalaria (Gastropoda: Planorbidae): Inference from a Multilocus Approach. Zool. J. Linn. Soc. 165 (4), 795-808. doi:10.1111/j.1096-3642.2012.00829.x

Collado, G. A., and Méndez, M. A. (2013). Microgeographic Differentiation Among Closely Related Species of Biomphalaria(Gastropoda: Planorbidae) from the Andean Altiplano. Zool. J. Linn. Soc. 169 (3), 640-652. doi:10.1111/zoj.12073 
Collado, G. A., Vila, I., and Méndez, M. A. (2011). Monophyly, Candidate Species and Vicariance in Biomphalaria Snails (Mollusca: Planorbidae) from the Southern Andean Altiplano. Zool. Scr. 40 (6), 613-622. doi:10.1111/j.14636409.2011.00491.x

Cuevas, C. C., Formas, J. R., Alvarado-Rybak, M., Peñafiel-ricaurte, A., and Azat, C. (2020). Rediscovery of the Enigmatic Andean Frog Telmatobius Halli Noble (Anura: Telmatobiidae), Re-description of the Tadpole and Comments on New Adult's Characters, Type Locality and Conservation Status. Zootaxa 4834 (2), 195-206. doi:10.11646/zootaxa.4834.2.2

Devictor, V., Mouillot, D., Meynard, C., Jiguet, F., Thuiller, W., and Mouquet, N. (2010). Spatial Mismatch and Congruence Between Taxonomic, Phylogenetic and Functional Diversity: The Need for Integrative Conservation Strategies in a Changing World. Ecol. Lett. 13 (8), 1030-1040. doi:10.1111/j.14610248.2010.01493.x

Díaz, C., and Maidana, N. (2005). Diatomeas de los salares de Atacama y Punta Negra II región. La Reina, Chile: Centro de Ecología Aplicada.

Díaz, C., Molina, X., and Montecino, V. (2016). "Preparación de muestras y análisis microscópicos," in Manual para el Monitoreo e Identificación de la Microalga Bentónica Didymosphenia geminata. Editors C. A. Díaz, F. T. F Salcedo, M. P. Olivares, and N. I. Maidana (Santiago, Chile: Subsecretaría de Pesca y Acuicultura, Gobierno de Chile), 55-57.

Dorador, C., Molina, V., Hengst, M., Eissler, Y., Cornejo, M., Fernández, C., et al. (2020). "Microbial Communities Composition, Activity, and Dynamics at Salar de Huasco: A Polyextreme Environment in the Chilean Altiplano," in Microbial Ecosystems in Central Andes Extreme Environments. Editor M. Farías (Cham: Springer), 123-139. doi:10.1007/978-3-030-36192-1_9

Dorador, C., Pardo, R., and Vila, I. (2003). Variaciones temporales de parámetros físicos, químicos y biológicos de un lago de altura: el caso del lago Chungará. Rev. Chil. Hist. Nat. 76 (1), 15-22. doi:10.4067/s0716-078x2003000100002

Dorador, C., Vila, I., Witzel, K.-P., and Imhoff, J. F. (2013). Bacterial and Archaeal Diversity in High Altitude Wetlands of the Chilean Altiplano. Fal 182 (2), 135-159. doi:10.1127/1863-9135/2013/0393

El-Sheekh, M. M., El-Naggar, A. H., Osman, M. E. H., and El-Mazaly, E. (2003). Effect of Cobalt on Growth, Pigments and the Photosynthetic Electron Transport in Monoraphidium Minutum and Nitzchia Perminuta. Braz. J. Plant Physiol. 15 (3), 159-166. doi:10.1590/S167704202003000300005

Flores-Varas, A., Heine-Fuster, I., López-Allendes, C., Pizarro, H., Castro, D., Luque, J. A., et al. (2021). Ascotán and Carcote Salt Flats as Sensors of Humidity Fluctuations and Anthropic Impacts in the Transition Zone of the Andean Altiplano. J. South Am. Earth Sci. 105, 102934. doi:10.1016/j.jsames.2020.102934

Fritz, S. C., Baker, P. A., Tapia, P., Spanbauer, T., and Westover, K. (2012). Evolution of the Lake Titicaca Basin and its Diatom Flora over the Last 370,000 Years. Palaeogeogr. Palaeoclimatol. Palaeoecol. 317-318, 93-103. doi:10.1016/j.palaeo.2011.12.013

García-Sanz, I., Heine-Fuster, I., Luque, J. A., Pizarro, H., Castillo, R., Pailahual, M., et al. (2021). Limnological Response from High-Altitude Wetlands to the Water Supply in the Andean Altiplano. Sci. Rep. 11 (1), 1-13. doi:10.1038/s41598-021$87162-6$

Gutiérrez-Cánovas, C., Millán, A., Velasco, J., Vaughan, I. P., and Ormerod, S. J. (2013). Contrasting Effects of Natural and Anthropogenic Stressors on Beta Diversity in River Organisms. Glob. Ecol. Biogeogr. 22 (7), 796-805. doi:10.1111/geb.12060

Gutiérrez-Cánovas, C., Sánchez-Fernández, D., Velasco, J., Millán, A., and Bonada, N. (2015). Similarity in the Difference: Changes in Community Functional Features Along Natural and Anthropogenic Stress Gradients. Ecology 96 (9), 2458-2466. doi:10.1890/14-1447.1

Hanson, C. A., Fuhrman, J. A., Horner-Devine, M. C., and Martiny, J. B. H. (2012). Beyond Biogeographic Patterns: Processes Shaping the Microbial Landscape. Nat. Rev. Microbiol. 10 (7), 497-506. doi:10.1038/nrmicro2795

Heino, J., Schmera, D., and Erős, T. (2013). A Macroecological Perspective of Trait Patterns in Stream Communities. Freshw. Biol. 58 (8), 1539-1555. doi:10.1111/ fwb. 12164

Hill, M. J., Heino, J., Thornhill, I., Ryves, D. B., and Wood, P. J. (2017). Effects of Dispersal Mode on the Environmental and Spatial Correlates of Nestedness and Species Turnover in Pond Communities. Oikos 126 (11), 1575-1585. doi:10.1111/oik.04266
Hsu-Kim, H., Eckley, C. S., Achá, D., Feng, X., Gilmour, C. C., Jonsson, S., et al. (2018). Challenges and Opportunities for Managing Aquatic Mercury Pollution in Altered Landscapes. Ambio 47 (2), 141-169. doi:10.1007/s13280-017-1006-7

Iltis, A., Risacher, F., and Servant-vildary, S. (1984). Contribution à l'étude hydrobiologique des lacs salés du Sud de l'Altiplano bolivien. Revue d'Hydrobiologie Tropicale 17, 259-273.

Jacobsen, D., and Dangles, O. (2017). Ecology of High Altitude Waters. Oxford, UK: Oxford University Press, 250.

Jamoneau, A., Passy, S. I., Soininen, J., Leboucher, T., and Tison-Rosebery, J. (2018). Beta Diversity of Diatom Species and Ecological Guilds: Response to Environmental and Spatial Mechanisms Along the Stream Watercourse. Freshw. Biol. 63 (1), 62-73. doi:10.1111/fwb.12980

Jost, L. (2006). Entropy and Diversity. Oikos 113 (2), 363-375. doi:10.1111/ j.2006.0030-1299.14714.x

Krammer, K., and Lange-Bertalot, H. (1986-1991). "Bacillariophyceae," in Sußwasserflora von Mitteleuropa. Editors H. Ettl, J. Gerloff, H. Heynig, and D. Mollenhauer (Stuttgart: Fischer-Verlag), 1-5.

Lai, G. G., Beauger, A., Wetzel, C. E., Padedda, B. M., Voldoire, O., Lugliè, A., et al. (2019). Diversity, Ecology and Distribution of Benthic Diatoms in Thermomineral Springs in Auvergne (France) and Sardinia (Italy). PeerJ 7, e7238. doi:10.7717/peerj. 7238

Leprieur, F., Tedesco, P. A., Hugueny, B., Beauchard, O., Dürr, H. H., Brosse, S., et al. (2011). Partitioning Global Patterns of Freshwater Fish Beta Diversity Reveals Contrasting Signatures of Past Climate Changes. Ecol. Lett. 14 (4), 325-334. doi:10.1111/j.1461-0248.2011.01589.x

López, M., and Vargas, E. (2021). "Ecología y economía en proyecciones ambientales espurias para salares altoandinos," in Salares Andinos. Editor R. Morales (San Pedro de Atacama, Chile: Fundación Tantí), 153-161. https://cl.boell.org/sites/default/files/202012/Libro\%20Salares\%20Andinos\%20OPSAL.pdf.

Luebert, F., and Pliscoff, P. (2006). Sinopsis bioclimática y vegetacional de Chile. Santiago Chile: Editorial Universitaria, 316.

Luís, A. T., Teixeira, P., Almeida, S. F. P., Ector, L., Matos, J. X., and Ferreira da Silva, E. A. (2009). Impact of Acid Mine Drainage (AMD) on Water Quality, Stream Sediments and Periphytic Diatom Communities in the Surrounding Streams of Aljustrel Mining Area (Portugal). Water Air Soil Pollut. 200 (1), 147-167. doi:10.1007/s11270-008-9900-z

MacArthur, R. H. (1965). Patterns of Species Diversity. Biol. Rev. 40, 510-533. doi:10.1111/j.1469-185X.1965.tb00815.x

Maddock, I. (1999). The Importance of Physical Habitat Assessment for Evaluating River Health. Freshw. Biol 41, 373-391. doi:10.1046/j.1365-2427.1999.00437.x

Marazuela, M. A., Vázquez-Suñé, E., Ayora, C., García-Gil, A., and Palma, T. (2019). Hydrodynamics of Salt Flat Basins: The Salar de Atacama Example. Sci. Total Environ. 651, 668-683. doi:10.1016/j.scitotenv.2018.09.190

Marazuela, M. A., Vázquez-Suñé, E., Ayora, C., and García-Gil, A. (2020). Towards More Sustainable Brine Extraction in Salt Flats: Learning from the Salar de Atacama. Sci. Total Environ. 703, 135605. doi:10.1016/j.scitotenv.2019.135605

Márquez-García, M., Vila, I., Hinojosa, L. F., Méndez, M. A., Carvajal, J. L., and Sabando, M. C. (2009). Distribution and Seasonal Fluctuations in the Aquatic Biodiversity of the Southern Altiplano. Limnologica 39 (4), 314-318. doi:10.1016/j.limno.2009.06.007

Menegotto, A., Dambros, C. S., and Netto, S. A. (2019). The Scale-dependent Effect of Environmental Filters on Species Turnover and Nestedness in an Estuarine Benthic Community. Ecology 100 (7), e02721. doi:10.1002/ecy.2721

Morales, E. A., Novais, M. H., Chávez, G., Hoffmann, L., and Ector, L. (2012). Diatoms (Bacillariophyceae) from the Bolivian Altiplano: Three New Araphid Species from the Desaguadero River Draining Lake Titicaca. Fottea 12, 41-58. doi:10.5507/FOT.2012.004

Morin, S., Duong, T. T., Dabrin, A., Coynel, A., Herlory, O., Baudrimont, M., et al. (2008). Long-term Survey of Heavy-Metal Pollution, Biofilm Contamination and Diatom Community Structure in the Riou Mort Watershed, South-West France. Environ. Pollut. 151 (3), 532-542. doi:10.1016/j.envpol.2007.04.023

Murphy, J., and Riley, J. P. (1962). A Modified Single Solution Method for the Determination of Phosphate in Natural Waters. Analytica Chim. Acta 27, 31-36. doi:10.1016/s0003-2670(00)88444-5

Oksanen, J., Blanchet, F. G., Friendly, M., Kindt, R., Legendre, P., McGlinn, D., et al. (2019). Vegan: Community Ecology Package. R package version 2, 5-6. Available at: https://rdrr.io/cran/vegan/ (Accessed September 28, 2020). 
Passy, S. I., and Blanchet, F. G. (2007). Algal Communities in Human-Impacted Stream Ecosystems Suffer Beta-Diversity Decline. Divers. Distrib. 13 (6), 670-679. doi:10.1111/j.1472-4642.2007.00361.x

Passy, S. I. (2007). Diatom Ecological Guilds Display Distinct and Predictable Behavior along Nutrient and Disturbance Gradients in Running Waters. Aquat. Bot. 86 (2), 171-178. doi:10.1016/j.aquabot.2006.09.018

Qian, H., Ricklefs, R. E., and White, P. S. (2005). Beta Diversity of Angiosperms in Temperate Floras of Eastern Asia and Eastern North America. Ecol. Lett. 8 (1), 15-22. doi:10.1111/j.1461-0248.2004.00682.x

R Core Team (2019). R: A Language and Environment for Statistical Computing. Vienna, Austria: R Foundation for Statistical Computing. Available at: https://www.R-project.org/.

Rimet, F., and Bouchez, A. (2012). Life-forms, Cell-Sizes and Ecological Guilds of Diatoms in European Rivers. Knowl. Managt. Aquat. Ecosyst. 406, 1. doi: $10.1051 / \mathrm{kmae} / 2012018$

Rimet, F., and Bouchez, A. (2011). Use of Diatom Life-Forms and Ecological Guilds to Assess Pesticide Contamination in Rivers: Lotic Mesocosm Approaches. Ecol. Indicators 11 (2), 489-499. doi:10.1016/j.ecolind.2010.07.004

Rumrich, U., Lange-Bertalot, H., and Rumrich, M. (2000). Diatoms of the Andes. From Venezuela to Patagonia/Tierra del Fuego, and Two Additional Contributions. Iconographia diatomologica. Editor H. Lange-Bertalot 9, 1-673.

Salmaso, F., Quadroni, S., Compare, S., Gentili, G., and Crosa, G. (2019). Benthic Diatoms as Bioindicators of Environmental Alterations in Different Watercourses of Northern Italy. Environ. Monit. Assess. 191 (3), 158. doi:10.1007/s10661-019-7290-x

Saunders, W. M. H., and Williams, E. G. (1955). Observations on the Determination of Total Organic Phosphorus in Soils. J. Soil Sci. 6 (2), 254-267. doi:10.1111/j.1365-2389.1955.tb00849.x

Servicio Nacional de Geología y Minería (2017). Ficha Técnica Salar de Ascotán. Available at: https://portalgeo.sernageomin.cl/Salares/SALAR_DE_ASCOTAN/ FICHA_TECNICA_COMPILADA_SALAR_DE_ASCOTAN.pdf (Accessed October 5, 2020).

Shmida, A., and Wilson, M. V. (1985). Biological Determinants of Species Diversity. J. Biogeogr. 12, 1-20. doi:10.2307/2845026

Smucker, N. J., and Vis, M. L. (2010). Using Diatoms to Assess Human Impacts on Streams Benefits from Multiple-Habitat Sampling. Hydrobiologia 654 (1), 93-109. doi:10.1007/s10750-010-0373-x

Soininen, J., Jamoneau, A., Rosebery, J., and Passy, S. I. (2016). Global Patterns and Drivers of Species and Trait Composition in Diatoms. Glob. Ecol. Biogeogr. 25 (8), 940-950. doi:10.1111/geb.12452

Sonter, L. J., Dade, M. C., Watson, J. E. M., and Valenta, R. K. (2020). Renewable Energy Production Will Exacerbate Mining Threats to Biodiversity. Nat. Commun. 11 (1), 1-6. doi:10.1038/s41467-020-17928-5

Squeo, F. A., Warner, B. G., Aravena, R., and Espinoza, D. (2006). Bofedales: High Altitude Peatlands of the central Andes. Rev. Chil. Hist. Nat. 79 (2), 245-255. doi:10.4067/s0716-078x2006000200010
Stevenson, R. J., and Bahls, L. L. (1999). "Periphyton Protocols," in Rapid Bioassessment Protocols for Use in Wadeable Streams and Rivers: Periphyton, Benthic Macroinvertebrates, and Fish. Editors M. T. Barbour, J. Gerritsen, and B. D. Snyder (Washington, DC: US Environmental Protection Agency), 6$1-6-22$.

Tapia, J., and Audry, S. (2013). Control of Early Diagenesis Processes on Trace Metal (Cu, Zn, Cd, Pb and U) and Metalloid (As, Sb) Behaviors in Mining- and Smelting-Impacted Lacustrine Environments of the Bolivian Altiplano. Appl. Geochem. 31, 60-78. doi:10.1016/j.apgeochem.2012.12.006

Tapia, J., Murray, J., Ormachea, M., Tirado, N., and Nordstrom, D. K. (2019). Origin, Distribution, and Geochemistry of Arsenic in the Altiplano-Puna Plateau of Argentina, Bolivia, Chile, and Perú. Sci. Total Environ. 678 (15), 309-325. doi:10.1016/j.scitotenv.2019.04.084

Tucker, M. E. (2009). Sedimentary Petrology: An Introduction to the Origin of Sedimentary Rocks. Hoboken, NJ: Blackwell Science Ltd, 11-65.

Vila, I., Mendez, M. A., Scott, S., Morales, P. M., and Poulin, E. (2007). Threatened Fishes of the World: Orestias Ascotanensis Parenti, 1984 (Cyprinodontidae). Environ. Biol. Fish. 80 (4), 491-492. doi:10.1007/ s10641-006-9150-0

Vila, I., Morales, P., Scott, S., Poulin, E., Véliz, D., Harrod, C., et al. (2013). Phylogenetic and Phylogeographic Analysis of the Genus Orestias (Teleostei: Cyprinodontidae) in the Southern Chilean Altiplano: the Relevance of Ancient and Recent Divergence Processes in Speciation. J. Fish. Biol. 82 (3), 927-943. doi: $10.1111 /$ jfb.12031

Wright, D. H., and Reeves, J. H. (1992). On the Meaning and Measurement of Nestedness of Species Assemblages. Oecologia 92 (3), 416-428. doi:10.1007/ bf00317469

Conflict of Interest: The authors declare that the research was conducted in the absence of any commercial or financial relationships that could be construed as a potential conflict of interest.

Publisher's Note: All claims expressed in this article are solely those of the authors and do not necessarily represent those of their affiliated organizations, or those of the publisher, the editors and the reviewers. Any product that may be evaluated in this article, or claim that may be made by its manufacturer, is not guaranteed or endorsed by the publisher.

Copyright (c) 2021 Heine-Fuster, López-Allendes, Aránguiz-Acuña and Véliz. This is an open-access article distributed under the terms of the Creative Commons Attribution License (CC BY). The use, distribution or reproduction in other forums is permitted, provided the original author(s) and the copyright owner(s) are credited and that the original publication in this journal is cited, in accordance with accepted academic practice. No use, distribution or reproduction is permitted which does not comply with these terms. 